\title{
Impact of Strategic Leadership Competencies on Enhancing Core Competencies in Organizations: Applied Study on AlManaseer Group for Industrial \& Trading
}

\author{
Hani J. Irtaimeh ${ }^{1}$ \\ ${ }^{1}$ Management Department, Business and Finance School, World Islamic Science \& Education University (WISE), \\ Amman, Jordan \\ Correspondence: Hani J. Irtaimeh, Business and Finance School, World Islamic Science \& Education University \\ (WISE), Amman, Jordan. E-mail: drhaniirtaimeh@yahoo.com
}

Received: June 11, 2018 Accepted: September 20, 2018 Online Published: October 29, 2018

doi:10.5539/mas.v12n11p169

URL: https://doi.org/10.5539/mas.v12n11p169

\begin{abstract}
The aim of this study is to explore the impact of Strategic leadership competencies dimensions (Strategic Thinking Competencies, Leadership Competencies) on core competency in AlManaseer Group for Industrial \& Trading. For this purpose, a questionnaire was developed to collect data from the study population which consists of 180 leaders. This is aimed at testing the hypotheses and achieving the objectives of the study. The most important results that the study achieved were that there was a statistically significant impact of Strategic leadership competencies with its dimensions (Strategic thinking competencies, leadership competencies) on core competency. The most important recommendations of the study were the necessity of AlManaseer Group should evaluate the core competencies; periodically and continuously in order to rebuild the critical resources which are the pillars of core competencies and in line with the requirements and conditions of strategic thinking and leadership competencies.
\end{abstract}

Keywords: strategic leadership competencies, strategic thinking competencies, leadership competencies, core competency, Jordan

\section{Research Introduction, Problem \& Aims}

Business organizations face a challenging future that characterized with uncertainty, high risks, high competitiveness, and speed of technology advents. Markets are becoming more diverse and complex than ever with globalization. Sustain at highly competition, business organizations require not only to possess new talent employees and Intellectual Capital but also to engage them to achieve strategic goals (Irtaimeh et al., 2016; Obeidat et al., 2017). Therefore, leaders and managers should be aware and alert if they want to achieve growth and profit targets. As environmental turbulence increases, strategic issues and options become more sensitive to their development. It would enable a better understanding of capability needed to respond to various levels of environmental turbulence.

In turbulent environments, strategic leadership becomes more important than ever to steering their businesses during the intensified competition and thus the quality of leadership is critical (Joyce, 2012; AlHrassi et al., 2016; AL-Syaidh et al., 2016). In the late 1980s, many social science researchers have gone on a debate whether leadership could make a difference in organizations while some others suggested that study of leadership has reached a culminating point. Moreover, leadership plays a pivotal role inside organizations concerning its strategic orientation (and Options). Nowadays, the study of leadership has been rebranded again as that would make them able to lead and steer the organization during the tough situations. In the era of global markets, organizations start to widening up and diversifying their operations to compete locally, regionally, globally, and internationally for successful growth and survival; therefore, strategic leaders require certain competencies such as strategic thinking, strategic vigilance, change management, and shared values \& a clear vision (Norzailan, Yusof, \& Othman, 2016).

\subsection{Problem Statement}

Strategic leadership literatures have identified long lists of competencies relating to leadership for effective management. Admittedly, the dynamic and rapidly evolving environment produce increasing uncertainty, 
complexity, and higher competition, hence, organizations suffer from lacking highly skilled leaderships. As long as complicated situations emerging, leaders should learn effectively how to manage and lead strategic plans that are requiring supplemental critical skills and competencies regardless of the level of leadership involved and thus adding more competencies to their profiles. Notwithstanding, many strategic leadership missed their direction and failed to keep organization on the right path. Therefore, the strategic leadership competencies and the particular core competencies required will be investigated in this study.

\subsection{Research Questions}

Towards realizing the broad objective, this study will provide answers to the following questions:

1. What are the competencies required for effective strategic leadership?

2. Which of the competencies required for effective strategic leadership are core?

3. Is level of experience a factor in identifying the core competencies?

4. Are the core competencies identified for traditional leadership adequate for effective strategic leadership?

\subsection{Aims of Study}

Smart and professional leaders in all cases require competencies in unique technical and personal skills. An investigation into the nature and impacts of the most critical of these leadership competencies required for strategic leadership is the focus of this study. It will highlight the impact of strategic leadership competencies on core competencies of the organizations which reflect on performance as a whole. This paper also studies strategic leadership competencies in the context of an economic turmoil which has posed great challenges for Jordan's organizations.

\section{Literature Review}

\subsection{Previous Studies}

Mapetere, Mavhiki, Nyamwanza, Sikomwe, \& Mhonde (2012) conducted a study to explore the link between active leadership involvement and strategy implementation success in State-Owned-Enterprises in Zimbabwe. The study revealed that a relatively low leadership involvement in strategy implementation leading to partial strategy success. Leadership has been failing to role model the ideal behavior necessary for successful strategy implementation. The absence of a well-crafted strategic vision and the lack of communication were also identified. The study concluded that leadership should be able to craft a vision for any strategic program, design effective communication strategies as well as to role model behavior changes that are consistent with new strategies. Al-Zoubi (2012) examined the impact of leadership competencies on competitive advantage in the Jordan Telecommunication Industry (JTI). A survey was administered over the middle line managers including supervisors and team leaders. The study found that leadership competencies had a significant impact on Jordanian Telecommunication Companies as well as a strong relationship exists between leadership competencies and competitive advantage.

Moreover, Eldakak (2014) discussed the essential leadership skills and competencies during the crises facing the organizations and how to deal with them effectively. His study consternates on the competencies that should each strategic leadership have them to manage the situations more effectively and achieve the targets. Hirschi \& Jones (2009) demonstrated that strategic leadership has clarity of vision and ability to develop competencies required to attuned organization goals and thus they understand their market and resources well. The results show that the characteristics and skills of strategic leaders play a dominant role in their ability to see the big picture, embedding these into daily business is crucial. Also it found that national culture, competitiveness and market development affect strategic leadership. Eventually, strategic leadership is associated with business success (Shannak \& Obeidat, 2012) and a lack of strategic leadership may find companies losing focus in the long term.

Maarten \& Mikhail (2010) explore the building strategic leadership competencies in global firms working at the Russian business environment after post-communist regime as contributors to successful corporate growth. A serious breakdown faces most companies related to cultural diffusion with visible gaps between typical behaviors and perceived managers' values. They admitted that to achieve strategic success by better understanding the link between strategy and anticipated managers' behaviors, leadership competencies must be considering analysis of Leadership Growth Profile (LGP). Consequently, they observed that leadership competencies are contingent in their nature. Not surprisingly, Wan (2013) agreed with Maarten \& Mikhail (2010) point of view about that the context is very important where leaders can enhance and execute their competencies based on their core competencies. Thus, nowadays empowering leaders are more acceptable than ever by their 
followers to bring greater organizational success. Norzailan, Yusof, \& Othman (2016) proposed that strategic leaders develop three key and distinctive competencies needed to run their duties in the turbulent environment to get competitive advantage, these competencies are strategic thinking, managing policies, and change management. They concluded that these competencies are achievable through a training programs and the training program should accommodate three important elements; deliberate practice, experience density and reflective learning, which are a part of the triangle that supports the development of strategic leadership competencies. As long as these supporting the accumulated competencies of leaders, organizations will obviously possess knowledgeable and professional strategic leaders with core competencies available for more strategic success.

\subsection{Leadership \& Strategic Leadership}

Strategic leadership must have the ability to manage through others and influence them, and the Strategic leadership competencies, through its dimensions (Strategic Thinking Competencies, Leadership Competencies), helps the managerial leaders of an organization to perceive and interpret their role in enhancing the organization's core competency. For this reason, we may assume that Strategic leadership competencies have an impact on core competency in an organization. Leadership is an engine for organizations to struggle for growth and survival. Finding good and excellent leaders have always been a crucial issue for all sorts of organizations (Trapp, 2014; Obeidat et al., 2017). Mainly, strategic leadership can be found at all levels of organization, at the top level where business units are formulated, at the middle level where the main strategy top down translated into different business unit strategies (regional, global, and international), and at the departmental level where strategic goals are translated into reality and executing them.

Strategic leadership is a complex form of leadership in organizations. It means that the leader must have the ability to manage through others. Being a strategic leader requires the ability to anticipate, envision, maintain flexibility, and empower others to create strategic change as necessary. Strategically thinking, a strategic leadership is mandatory to run the ongoing change through continuous improvements to employees and processes used, in other words, their main role is to keep and sustain organizational resources and capabilities while searching for another extended resources that support its strategic goals. Strategic leadership must be alert and carefully make balance between analytics and process development and human dimension. By and large, the harmonized team leaders and employees that understand common tools, framework, and templates for success, is a very promising future for the organization to start smoothly and grow up very fast. Concretely, the new era of the 21 st century requires different leaders to contribute more to their organizations; those leaders face tremendous pressure and challenges such as building peoples' ability to innovate, inspiring others to perform harder, stimulating their high potentials, and understanding of rapidly changing technological advancements. Therefore, leaders require more skills, knowledge, capabilities, abilities, and competencies that would certainly achieve organizational strategic goals.

\subsection{Competence Vs. Competency}

The term of competency has various definitions and it was originated at McClelland works in 1973 used it as replacement to intelligence tests (McClelland, 1973). The term is closely related to ability but there is different between the meanings of synonymous words. Ability usually refers to the able to do something and need special talents while competency refers to the experience or expertise. Noteworthy, competence doesn't equal to competency, the latter is behavioral-based which related to individual characteristics and personality while the first is skill-based that can be trained and practiced. McClelland developed certain competencies for each position based on behavioral interviews with employees and top management (Northouse, 2004).

\subsection{Core Competencies \& Leadership Competency}

The concept of core competencies was developed by Gary Hamel and C. K. Prahalad (1990) to explain that organizations can easily face the challenges to sustain their strategic position (Prahalad \& Hamel, 1994 and 2001; Wikipedia, 2016). It can be defined as "a harmonized combination of multiple resources and skills that distinguish a firm in the marketplace" (Schilling, 2013). Gallon, Stillman, \& Coates (1995) defined it as "an aggregates of capabilities, where synergy is created that has sustainable value and broad applicability". Moreover, Coyne, Hall, \& Clifford (1997) defined core competencies as "a combination of complementary skills and knowledge bases embedded in a group or team that results in the ability to execute one or more critical processes to a world class standard". Hence, Core competencies are the set of skills which are crucial to a business, for them to gain a competitive advantage in their market.

The term "core competencies" was introduced to Baldrige Glossary Definition on late 2007 which define it as an 
organization's areas of greatest expertise. An organization's core competencies are those strategically important capabilities that are central to fulfilling its mission or a distinctive competence that provides a firm a competitive advantage in its industry (Baldrige Glossary Definition, 2007). Core competencies frequently are challenging for competitors or suppliers and partners to imitate. Absence of a needed core competency may result in a significant strategic challenge or disadvantage in the marketplace. Core competencies may involve technology expertise, unique service offerings, a marketplace niche, or particular business acumen (e.g., business acquisitions). Core competencies focus on an organization's internal capacities and deep proficiencies that enable a company to deliver unique value to customers. Core competencies also contribute substantially to the benefits a company's products offer customers (Masa'deh et al., 2008; Nair, 2014; Kateb et al., 2015). The distinguishing characteristic of an organization's core competencies are that they develop overtime and represent the continual accomplishment of a firm's critical success factors over time. Another distinguishing characteristic of a core competency is that it's hard for competitors to copy or procure (Rigby, 2015: 24).

By using Hamel and Prahalad core competency model, organizations can capable of developing unexpectedly and surprisingly new products that are matching Porter's cost-leadership strategy and faster than their rivals. Hamel and Prahalad model focuses on a combination of specific, collaboration, integrated and applied knowledge, skills and attitudes (Marino, 1996; Lawson, 1999), it consists of four core competencies (Figure 2); resources that requires for developing skills and technologies, capabilities the various possibilities to build up core competencies, competitive advantage the challenge to acquire and develop largest market share of core products, and strategy to develop largest market share of finished products (Van Vliet, 2011).

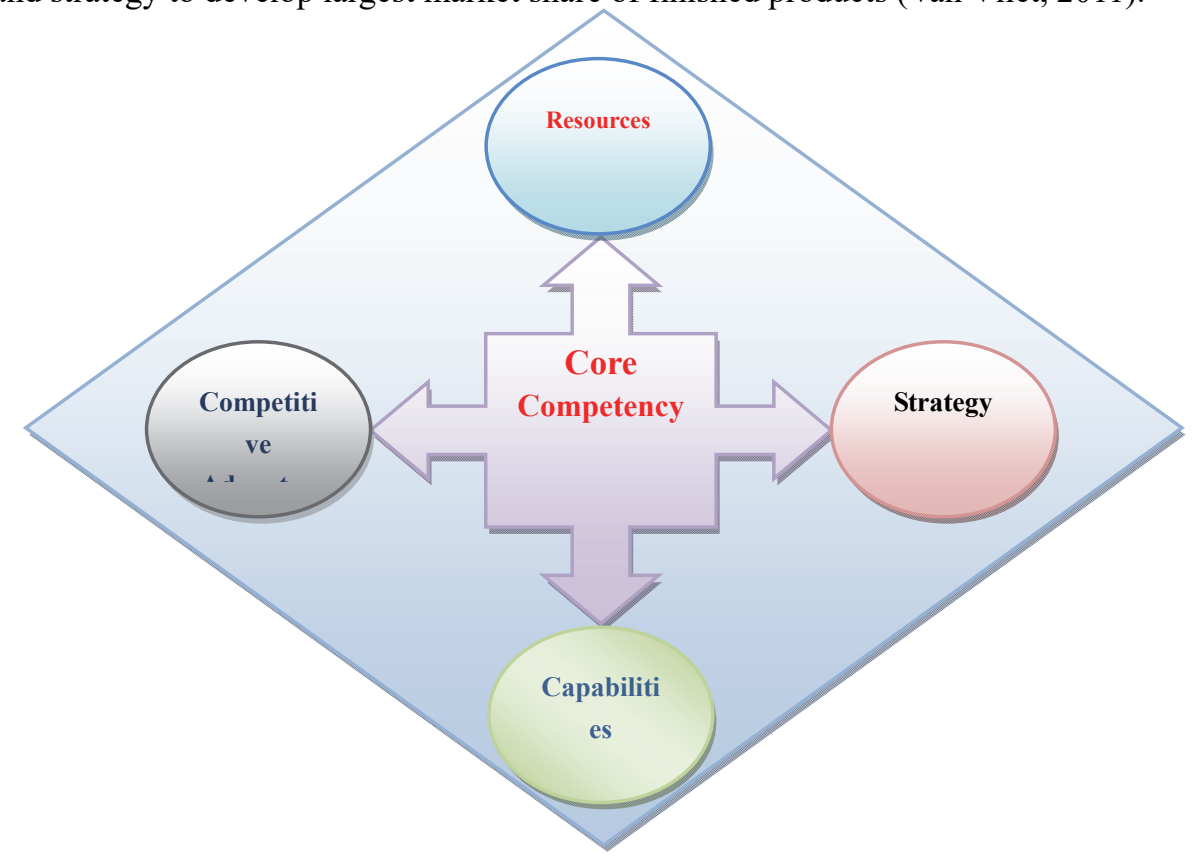

Figure 1. Hamel and Prahalad model

A company's competitiveness derives from its core competencies and core products (the tangible results of core competencies). Core competence is the collective learning in the organization, especially the capacity to coordinate diverse production skills and integrate streams of technologies. It is also a commitment to working across organizational boundaries. Organizing around core competencies requires a radical change in corporate organization. The first step requires identifying core competencies, which meet these three requirements: they provide potential access to a wide variety of markets, make a contribution to the customer benefits of the product, and are difficult for competitors to imitate. The next step is to redesign the architecture of the company and provide an impetus for learning from alliances and a focus for internal development (Prahalad \& Hamel, 1990).

As a result, effective leaders require competency in core skills. Expertise in core competencies associated with leadership roles typically enable a person to lead others, develop personnel, create a productive environment and get results. Successful organizations develop a competency model that shows the skills, attitudes, behaviors and knowledge required for their leaders and provide training that helps personnel further their careers. Additionally, senior leaders typically provide coaching and mentoring to less-experienced personnel to ensure leadership 
succession. Therefore, organizations seek to build a leadership competency model which basically divided into three levels:

1-Core Competencies at the base level, these are the personal skills required by leadership which is an essential for the foundation of competent leaders. It includes but not limited to basic communications, negotiation, teamwork, creative problem solving, interpersonal skills, manage client relationship, self-direction, flexibility, building necessary relationships, financial skills, business acumen.

2-Leadership Competencies at the middle level, grasping these competencies form a basic structure of separating leaders from bosses. Without these competencies, leaders are not any longer leaders. It is cannon in front of new cutting edge of technological menace. Leadership competencies include leadership abilities (role model, stimulating morals, and building trustiness), visioning process, create and lead teams, assess situations accurately and quickly, foster conflict resolutions with win-win situation, project management, employee involvement strategies, coach and train peers and subordinates.

3-Professional Competencies at top level, these are the skills and knowledge required by leaders to direct the systems and processes that leader control. These are including adult learning, instructional design, rapid design, and instructions.

\section{Research Model}

The study adopted the following study model of the study variables relationships, shown in Figure (1).

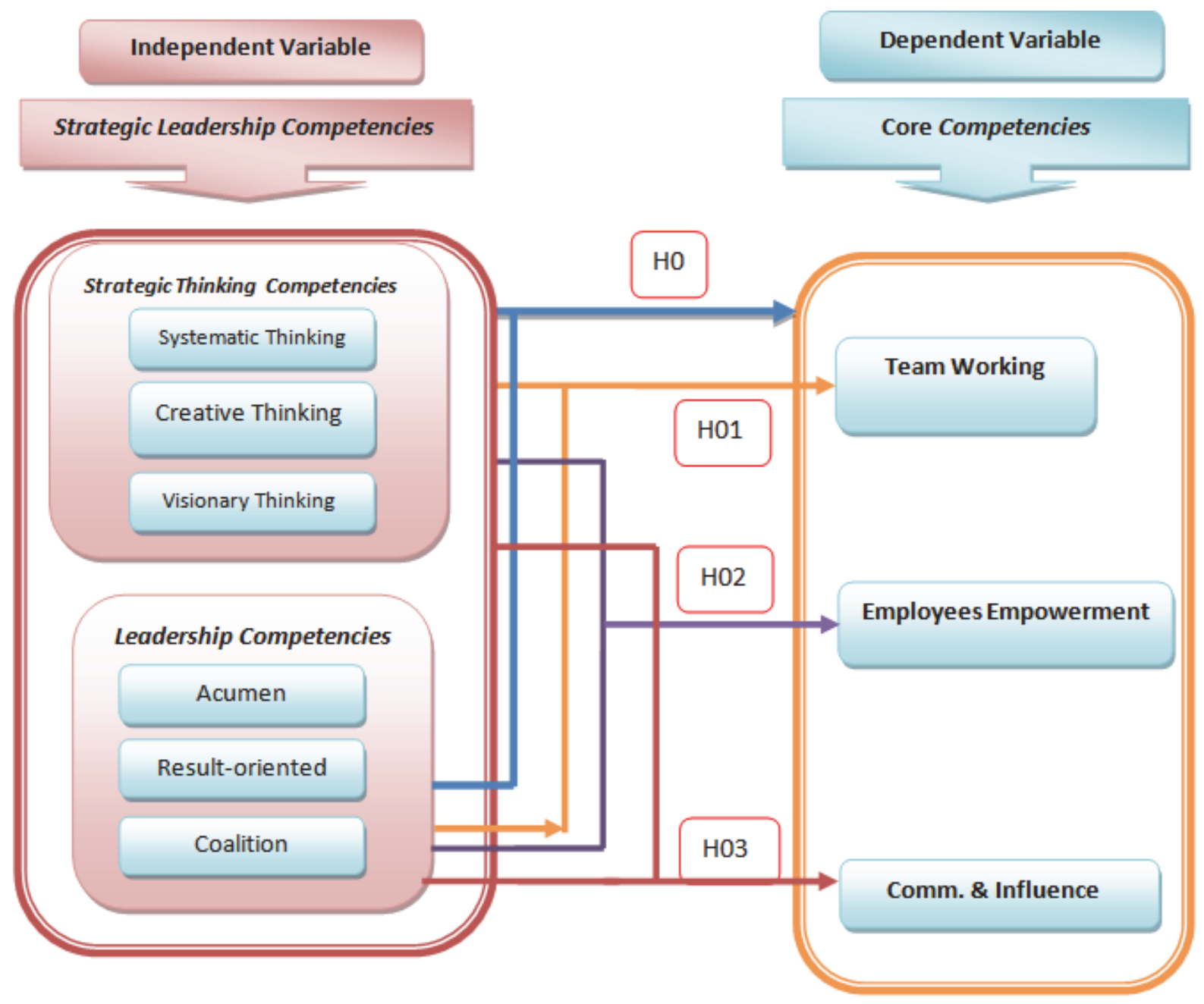

Figure 1. The research model

Figure (1) presents the research model prepared by the researcher supported from the following sources: 
The independent variable (Strategic Leadership Competencies): (Moon, 2013; Overby \& Suvanujasiri, 2012; Das et. al, 2011).

The dependent variable (core competencies): (Shaykhli \& Kubaisi, 2011).

\section{Research Hypothesis}

The study has one main hypothesis and three sub hypothesis, as following:

H01: The dimension of Strategic Leadership (Strategic Thinking Competencies, Leadership Competencies) does not significantly and positively affect the Core Competency in AlManaseer Group at $\alpha \leqslant 0.05$.

H01-1: The dimension of Strategic Leadership (Strategic Thinking Competencies, Leadership Competencies) does not significantly and positively affect the Team Working in AlManaseer Group at $\alpha \leqslant 0.05$.

H01-2: The dimension of Strategic Leadership (Strategic Thinking Competencies, Leadership Competencies) does not significantly and positively affect the Employees Empowerment in AlManaseer Group at $\alpha \leqslant 0.05$.

H01-3: The dimension of Strategic Leadership (Strategic Thinking Competencies, Leadership Competencies) does not significantly and positively affect the Comm. \& Influence in AlManaseer Group at $\alpha \leqslant 0.05$.

\section{Research Design and Methodology}

\subsection{Research Design}

For this study, a descriptive quantitative methodology was chosen to allow us to generate conclusions and results that can be generalized. The methodology is a formal and systematic process that makes use of numerical data in making deductive conclusions. This is achieved with the aid of a structured questionnaire. The questionnaire was drafted to obtain statistically useful information about the strategic leadership competencies required to enhance organization's core and critical competencies across different industries and positions. The questionnaires were administered by distributing and handing out to the respondents to be completed and collected back for subsequent analyses.

\subsection{Target Population}

The target population for this descriptive study is people occupying top management posts and middle management in AlManaseer for Industrial \& Trading Group. The focuses of this study are leaders irrespective of specialization. A well-structured questionnaire was used to obtain data from individuals that fall within the target population in the selected companies.

Cross tabulation and correlations will be used to associate between the variables, which in this case, are the strategic leadership competencies and core competencies required for effective strategic organizational executions.

\subsection{Population and Sample}

The population for this study consists of AlManaseer for Industrial \& Trading Group chosen because it has a strong brand name and it is implementing accelerated growth strategy in the different companies belongs to this group in Jordan. AlManaseer Group consists of 27 subsidiaries of the Group parent company, the study sample included all administrative leaders, and thus the size of the sample (180) as director of the occupants of managerial positions in the group AlManaseer companies.

\subsection{Data Collection and Instrument}

The study used a questionnaire for collection data of study. A survey instrument that had a (1-5) Likert scale was designed and developed in line with earlier studies to be fitted for Carrefour environment, and it consisted of three main sections; Section 1 focused on Demographical Variables; gender, age, educational background, experiences, and position, while the section 2, focuses on strategic leadership, eventually Section 3 emphasized on core competencies. 180 questionnaires were distributed on AlManaseer Group director. Only 168 were returned with a ratio of $93.3 \%$ and 162 were valid to statistically analysis.

\subsection{Instrument Validity and Reliability}

The instrument (questionnaire) was sent to a professional as well as specialists in the strategic management and strategy to test the face validity of the instrument; they did small corrections and split some items into two or three items to measure all the variables comprehensively. Other type was to test the internal consistency and stability of questionnaire, is conducting a pilot sample of 20 managers to assess the simplicity and clarity of all items, the results was as simple as clear to understand. Meanwhile, researchers used Cronbach Alpha to test the reliability of the questionnaire, and it is considered adequate if it is exceed 0.70 according to (Sekaran \& Bougie, 
2010, 290).

However, as depicted in table 1, the results of Alpha coefficients of the concerned variables were registered acceptable where the coefficients are above 0.70 . Therefore, the instrument were suitable and consistence for implementing the study.

Table 1. Reliability of the items used in this study

\begin{tabular}{|c|c|c|}
\hline Construct & No. of Items & Cronbach Alpha \\
\hline Strategic Leadership Competencies & 30 & \\
\hline Strategic Thinking Competencies & 15 & 0.903 \\
\hline Systematic Thinking & 5 & 0.837 \\
\hline Creative Thinking & 5 & 0.794 \\
\hline Visionary Thinking & 5 & 0.771 \\
\hline Leadership Competencies & 15 & 0.876 \\
\hline Acumen & 5 & 0.705 \\
\hline Result-oriented & 5 & 0.792 \\
\hline Coalition & 5 & 0.769 \\
\hline Core Competencies & 15 & 0.905 \\
\hline Team Working & 5 & 0.766 \\
\hline Employees Empowerment & 5 & 0.782 \\
\hline Comm. \& Influence & 5 & 0.837 \\
\hline Total & 45 & \\
\hline
\end{tabular}

\section{Data Analysis and Discussion}

In order to exploring the impact of independent variable(s) on dependent variable(s), a regression analysis was used. The hypothesis testing results are as follow:

H01: The dimension of Strategic Leadership (Strategic Thinking Competencies, Leadership Competencies) does not significantly and positively affect the core competency in AlManaseer Group at $\alpha \leqslant 0.05$.

Table 2. Regression results of strategic leadership dimension and core competencies

\begin{tabular}{|c|c|c|c|c|c|c|c|c|c|}
\hline \multirow{2}{*}{$\begin{array}{l}\text { Dependent } \\
\text { variable }\end{array}$} & \multirow[t]{2}{*}{$\mathrm{R}$} & \multirow[t]{2}{*}{$\mathrm{R}^{2}$} & \multirow{2}{*}{ 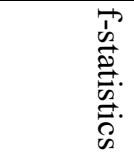 } & \multirow[t]{2}{*}{ Sig F. } & \multicolumn{5}{|c|}{ Regression coefficients } \\
\hline & & & & & $\begin{array}{l}\text { Independent } \\
\text { variable }\end{array}$ & $\beta$ & $\begin{array}{l}\text { Std } \\
\text { error }\end{array}$ & t-statistics & Sig. \\
\hline \multirow{2}{*}{$\begin{array}{l}\stackrel{8}{0} \\
\frac{3}{0} \\
0 \\
0 \\
0 \\
0 \\
0 \\
0 \\
0 \\
0\end{array}$} & 0.794 & 0.626 & 135,97 & 0.000 & $\begin{array}{c}\text { Strategic } \\
\text { thinking } \\
\text { competencies }\end{array}$ & 0.037 & 0.058 & 0.629 & 0.531 \\
\hline & & & & & $\begin{array}{l}\text { Leadership } \\
\text { competencies }\end{array}$ & 0.772 & 0.064 & 12.088 & 0.000 \\
\hline
\end{tabular}

* The effect is statistically significant at the level of $(\alpha \leqslant 0.05)$

Table (2) explores the regression analysis of hypothesis; results revealed that the Strategic Leadership is significantly affects the Core Competencies at $\mathrm{P} \leqslant 0.05$. $\left(\mathrm{R}^{2}=0.626, \mathrm{t}=12.088\right)$ which implies that the Strategic Leadership explains $62.6 \%$ of the variance of Core Competencies while the rest related to other factors not included in the model. In addition, if the leadership competencies is remarkably nurtured by 1 point, this will 
lead to effective to follow Core Competencies by $77.2 \%$, in the other hand the result shows that the dimension strategic thinking competencies has not significant effect on the core competencies this shown at the table above, but the total effect the Strategic Leadership is significant, this leads to reject the null hypothesis that saying "The dimension of Strategic Leadership (Strategic Thinking Competencies, Leadership Competencies) does not significantly and positively affect the core competency in AlManaseer Group at $\alpha \leqslant 0.05$ ", and accept the alternative hypothesis of affirming the effect.

H01-1: The dimension of Strategic Leadership (Strategic Thinking Competencies, Leadership Competencies) does not significantly and positively affect the Team Working in AlManaseer Group at $\alpha \leqslant 0.05$.

Table 3. Strategic leadership dimension (strategic thinking competencies, leadership competencies) and core competencies

\begin{tabular}{|c|c|c|c|c|c|c|c|c|c|}
\hline \multirow{2}{*}{$\begin{array}{c}\text { Dependent } \\
\text { variable }\end{array}$} & \multirow[t]{2}{*}{$\mathrm{R}$} & \multirow[t]{2}{*}{$\mathrm{R}^{2}$} & \multirow{2}{*}{ 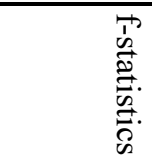 } & \multirow[t]{2}{*}{ Sig F. } & \multicolumn{5}{|c|}{ Regression coefficients } \\
\hline & & & & & $\begin{array}{c}\text { Independent } \\
\text { variable }\end{array}$ & $\beta$ & $\begin{array}{c}\text { Std } \\
\text { error }\end{array}$ & t-statistics & Sig. \\
\hline $\begin{array}{l}\overrightarrow{8} \\
\stackrel{8}{3}\end{array}$ & 0.76 & 0.571 & 108.293 & 0.000 & $\begin{array}{c}\text { Strategic } \\
\text { thinking } \\
\text { competencies }\end{array}$ & 0.183 & 0.066 & 2.694 & 0.008 \\
\hline 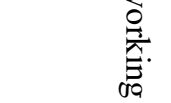 & & & & & $\begin{array}{l}\text { Leadership } \\
\text { competencies }\end{array}$ & 0.627 & 0.073 & 9.217 & 0.000 \\
\hline
\end{tabular}

* The effect is statistically significant at the level of $(\alpha \leqslant 0.05)$

As depicted on the table (3), results revealed that there is a positive correlation between Strategic Leadership and Team Working where the correlation coefficient $(R)$ is equal to 0.76 . Additionally, $\left(\mathrm{R}^{2}\right)$ is explained $57.1 \%$ of the variance in Team Working and $42.9 \%$ related to other factors not listed in this study. This confirms that Strategic Leadership with its two dimensions have a positive and significant effects on Team Working where the value of ( $F=108.293$, Sig. 0.000).

Regarding the dimensions of Strategic Leadership, strategic thinking competencies, Leadership competencies, table (3) shows that there are a significant and positive correlations with Team Working as the correlation coefficients of $(\mathrm{R}=0.76)$ respectively. Notably, the two dimensions of Strategic Leadership explain $18.3 \%$, and $62.7 \%$, of Team Working respectfully, while other factors related to non-listed in this study. Finally, the t-value is showing the significant and positive effect of these dimensions on dependent variable (Team Working). Supporting this is the Beta coefficient $(\beta=0.183,0.627)$ respectfully. By and large, from these results, it can be concluded that Leadership and its dimensions has a positive and significant relationships and effects on Team Working which are not supported our null hypothesis hence we reject it and accept the alternative hypothesis of affirming the relationships and effects.

H01-2: The dimension of Strategic Leadership (Strategic Thinking Competencies, Leadership Competencies) does not significantly and positively affect the Employees Empowerment in AlManaseer Group at $\alpha \leqslant 0.05$.

Table 4. Strategic leadership dimension (strategic thinking competencies, leadership competencies) and employees empowerment

\begin{tabular}{|c|c|c|c|c|c|c|c|c|c|}
\hline \multirow{2}{*}{$\begin{array}{l}\text { Dependent } \\
\text { variable }\end{array}$} & \multirow[t]{2}{*}{$\mathrm{R}$} & \multirow[t]{2}{*}{$\mathrm{R}^{2}$} & \multirow[b]{2}{*}{ 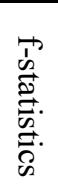 } & \multirow[t]{2}{*}{ Sig F. } & \multicolumn{5}{|c|}{ Regression coefficients } \\
\hline & & & & & $\begin{array}{c}\text { Independent } \\
\text { variable }\end{array}$ & $\beta$ & Std error & t-statistics & Sig. \\
\hline
\end{tabular}




\begin{tabular}{|c|c|c|c|c|c|c|c|c|c|}
\hline $\mathbb{5}$ & 0.727 & 0.522 & 88.97 & 0.000 & $\begin{array}{c}\text { Strategic } \\
\text { thinking } \\
\text { competencies }\end{array}$ & 0.138 & 0.074 & 1.919 & 0.057 \\
\hline 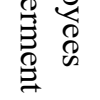 & & & & & $\begin{array}{c}\text { Leadership } \\
\text { competencies }\end{array}$ & 0.629 & 0.081 & 8.761 & 0.000 \\
\hline
\end{tabular}

* The effect is statistically significant at the level of $(\alpha \leqslant 0.05)$

As shown on the table 4, results revealed that there is a relationship between Strategic Leadership and Employees Empowerment where the correlation coefficient (R) is equal to 0.73. Additionally, $\left(\mathrm{R}^{2}\right)$ is explained 52.2\% of the variance in Employees Empowerment and 47.8\% related to other factors not included in the model. This confirms that Strategic Leadership with its two dimensions have a positive and significant effects on Employees Empowerment where the value of $(\mathrm{F}=88.97$, Sig. 0.000).

Regarding the dimensions of Strategic Leadership, strategic thinking competencies, Leadership competencies, table (4) shows that there are a significant and positive correlations with Employees Empowerment as the correlation coefficients of $(\mathrm{R}=0.73)$ respectively. Notably, the two dimensions of Strategic Leadership explain $7.4 \%$, and $62.9 \%$, of Employees Empowerment respectfully, while other factors related to non-listed in this study model. Finally, the t-value is showing the significant and positive effect of these dimensions on dependent variable (Employees Empowerment). Supporting this is the Beta coefficient $(\beta=0.138,0.629)$ respectfully. By and large, from these results, it can be concluded that Leadership and its dimensions has a positive and significant relationships and effects on Employees Empowerment which are not supported our null hypothesis hence we reject it and accept the alternative hypothesis of affirming the relationships and effects.

H01-3: The dimension of Strategic Leadership (Strategic Thinking Competencies, Leadership Competencies) does not significantly and positively affect the Comm. \& Influence in AlManaseer Group at $\alpha \leqslant 0.05$.

Table 5. Strategic leadership dimension (strategic thinking competencies, leadership competencies) and Comm. \& Influence

\begin{tabular}{|c|c|c|c|c|c|c|c|c|c|}
\hline \multirow{2}{*}{$\begin{array}{l}\text { Dependent } \\
\text { variable }\end{array}$} & \multirow[t]{2}{*}{$\mathrm{R}$} & \multirow[t]{2}{*}{$\mathrm{R}^{2}$} & \multirow{2}{*}{ 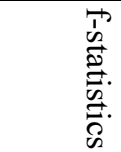 } & \multirow{2}{*}{$\begin{array}{l}\mathrm{Sig} \\
\mathrm{F} .\end{array}$} & \multicolumn{5}{|l|}{ Regression coefficients } \\
\hline & & & & & independent variable & $\beta$ & $\begin{array}{l}\text { Std } \\
\text { error }\end{array}$ & t-statistics & Sig. \\
\hline 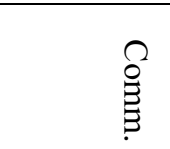 & 0.63 & 0.39 & 52.395 & 0.000 & $\begin{array}{c}\text { Strategic thinking } \\
\text { competencies }\end{array}$ & $0.182-$ & 0.094 & -2.237 & 0.027 \\
\hline 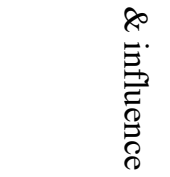 & & & & & $\begin{array}{l}\text { Leadership } \\
\text { competencies }\end{array}$ & 0.733 & 0.103 & 9.034 & 0.000 \\
\hline
\end{tabular}

* The effect is statistically significant at the level of $(\alpha \leqslant 0.05)$

As shown on the table (5), results revealed that there is a correlation between Strategic Leadership and Comm. \& Influence where the correlation coefficient $(\mathrm{R})$ is equal to 0.63 . Additionally, $\left(\mathrm{R}^{2}\right)$ is explained $39 \%$ of the variance in Comm. \& influence and $61 \%$ related to other factors not included in the model. This confirms that Strategic Leadership with its second dimensions Leadership Competencies has a positive and significant effect on Comm. \& Influence where the value of $(\mathrm{F}=52.395$, Sig. 0.000) and instead the strategic thinking competencies has negative significant effect on Comm. \& Influence. Regarding the dimensions of Strategic Leadership, table above shows that the Leadership competencies has significant and positive correlations with Comm. \& influence as the correlation coefficients of $(\mathrm{R}=0.63)$ respectively. Notably, the dimensions of strategic 
thinking competencies has opposite effect $(-18.2 \%)$ which means 1 point increasing in strategic thinking competencies leads to decreasing $18.2 \%$ in Comm. \& Influence, and in the other hand Leadership Competencies significant and positive effect on Comm. \& Influence $(\beta=0.733)$ respectfully. while other factors related to non-listed in this study. Finally, the t-value is showing the significant effect of these dimensions on dependent variable (Comm. \& Influence). Supporting this is the Beta coefficient $(\beta=-0.182,0.733)$ respectfully. By and large, from these results, it can be concluded that Leadership and its dimensions has a significant relationships and effects on Comm. \& Influence which are not supported our null hypothesis hence we reject it and accept the alternative hypothesis of affirming the relationships and effects.

\section{Conclusion \& Recommendations}

The results of this study showed a statistically significant impact for strategic leadership (Strategic Thinking Competencies, Leadership Competencies) on core competencies; a statistically significant impact of Leadership Competencies on core competencies; conversely there is not statistically significant impact Strategic Thinking Competencies on core competencies (we can explain this result; that strategic thinking is a process of intellectual and implicit Knowledge which it may not appear in the minds of managers, but appear on their actions and thus can miss the direct impact); a statistically significant impact of Strategic Thinking Competencies on (team working, communication \& influence), conversely there is not statistically significant impact Strategic Thinking Competencies on employees empowerment. A statistically significant impact of Leadership Competencies on (team working, employee's empowerment, \& communication \& influence). AlManaseer Group should give more importance to core competencies. That's because it is so critical to build the competitive advantage and reinforce and strengthen its competitive position.

AlManaseer Group should evaluate the core competencies; periodically and continuously in order to rebuild the critical resources which are the pillars of core competencies and in line with the requirements and conditions of strategic thinking and leadership competencies, and to ensure the achievement of its competitive advantages, through:

- Activate employee's empowerment at different managerial levels, and to consider the ideas provided by employees from the lower level as input to the upper level.

- The diversification of the tools used in the communication between the strategic leadership and employees, and that may have a role in influencing and directing employees to strengthen the competitive advantages and thus achieve the strategic objectives of the organization.

- Activate the cooperation both in problem solving or knowledge sharing across the tangible and moral intensives depending on team working.

\section{References}

AlHrassi, J., Al-Lozi, M., \& Irtaimeh, H. (2016). The impact of management innovation and technological innovation on organizational effectiveness: An empirical study from managerial staff perspective in Sultan Qaboos university. Journal of Social Sciences (COES\&RJ-JSS), 5(3), 309-339.

AL-Syaidh, N., Al- Lozi, M., \& AlHarrasi, J. (2016). Transformational leadership and its role on the effectiveness of employees' behavior: A theoretical study. Journal of Business \& Management (COES\&RJ-JBM), 4(1), 14-35.

Al-Zoubi, M. (2012). Leadership competencies and competitive advantage "Empirical study on Jordan telecommunications". European Journal of Business and Management, 4(7), 234-247.

American Psychological Association. (1972). Ethical standards of psychologists. Washington, DC: American Psychological Association.

Baldrige Glossary (2007). Core competency. Added to the Baldrige Glossary for 2007.

Coyne, K., Hall, J. D., \& Clifford, P. (1997). Is your core competence a mirage? McKinsey Quarterly, (Mar. 1), 40-55.

Das, Anupam, Kumar, Vinod \& Uma (2011). The role of leadership competencies for implementing TQM, International Journal of Quality\& Reliability Management, 28(2), 195-219.

Eldakak, S. (2014). Leadership in crises: The Ultimate Challenge. Advances in Economics and Business, 2(6), 232-237.

Gallon, M., Stillman, H., \& Coates, D. (1995). Putting core competency thinking into practice. Research Technology Management, 38(3), 20-29. 
Hirschi, G., \& Jones, M. (2009). Effects of strategic leadership on business success - "A cross-cultural analysis from a resource based view". MIBES Transactions, 3(1), 1-18.

Irtaimeh, H., Al-Azzam, Z., Al-Quraan, F., \& Atif, B. (2016). Impact of intellectual capital on Carrefour internal growth strategies (Ansoffs Model) in governorate of irbid. European Journal of Business and Management, $8(5)$, 53-66.

Joyce, P. (2012). Strategic Leadership in The public services. Routledge: USA.

Kateb, M., Swies, R., Obeidat, B., \& Maqableh, M. (2015). An investigation on the critical factors of information system implementation in Jordanian information technology companies. European Journal of Business and Management, 7(36), 11-28.

Lawson, C. (1999). Towards a competence theory of the region. Cambridge Journal of Economics, 23(2), 151-166.

Maarten, V. B., \& Mikhail, G. (2010). Building strategic leadership competencies: "The case of UNILIVER". International Journal of Leadership Studies, 5(3), 317-332.

Mapetere, D., Mavhiki, S., Nyamwanza, T., Sikomwe, S., \& Mhonde, C. (2012). Strategic role of leadership in strategy implementation in "Zimbabwe's State Owned Enterprises". International Journal of Business and Social Science, 3(16), 271-276.

Marino, K. E. (1996). Developing consensus on firm competencies and capabilities. The Academy of Management Executive, 10(3), 40-51.

Masa'deh, R., Hunaiti, Z., \& Bani Yaseen, A. (2008). An integrative model linking IT-business strategic alignment and firm performance: The mediating role of pursuing innovation and knowledge management strategies. Communications of the International Business Information Management Association (IBIMA) Journal.

McClelland, D. (1973). Testing for competence rather than for intelligence. American Psychologist, 28, 1-14.

Moon, B. (2013). Antecedents and outcomes of strategic thinking, Journal of Business Research, 66(10), $1698-1708$.

Nair, A. (2014). Strategy \& management tool. Retrieved from https://ajaysankarnair.wordpress.com/tag/tools/.

Northouse, P. (2004). Leadership theory and practice. Thousand Oaks, CA: Sage Publications.

Norzailan, Z., Yusof, S., \& Othman, R. (2016). Developing strategic leadership competencies. Journal of Advanced Management Science, 4(1), 66-71.

Obeidat, B., Hadidi, A., \& Tarhini, A. (2017). Factors affecting strategy implementation: A case study of pharmaceutical companies in the Middle East. Review of International Business and Strategy, 27(3), 386-408.

Obeidat, B., Tarhini, A., \& Aqqad, N. (2017). The impact of intellectual capital on innovation via the mediating role of knowledge management: A structural equation modeling approach. International Journal of Knowledge Management Studies, 8(3/4), 273-298.

Overby, J., \& Suvanujasiri, A. (2012). A second order confirmatory factor analysis of leadership competency model: "An empirical study conducted in Thailand". The Journal of Applied Business Research, 28(5), 1073-1084.

Prahalad, C. K., \& Hamel, G. (1994). Strategy as a field of study: Why search for a new paradigm? Strategic Management Journal, 15(S2), 5-16.

Prahalad, C. K., \& Hamel, G. (2001). The core competence of the corporation. Harvard Business Review, 79-91.

Rigby, D. (2015). Management tools 2015: Core competency. Bain \& Company Inc.

Schilling, M. A. (2013). Strategic management of technological Innovation, International Edition, McGraw-Hill Education.

Sekaran, U., \& Bogie, R. (2010). Research methods for business: "A skill building approach" (5 ${ }^{\text {th }}$ ed.), New York, NY: John Wiley \& Sons Inc.

Shannak, R., \& Obeidat, B. (2012). Culture and the implementation process of strategic decisions in Jordan. Journal of Management Research, 4(4), 257-281. 
Shaykhli, M., \& Kubaisi, S. A. (2011). The role of implicit knowledge in building the core competency, "Exploratory study to survey the views of a sample of the Supreme Audit managers in Iraq". Journal of Anbar University for Economic and Administrative Sciences, 3(6), 46-73.

Trapp, R. (2014). Successful organizations need leaders at all levels. Retrieved October 10, 2016, from http://www.forbes.com/sites/rogertrapp/2014/03/23/organizations-need-leaders-at-all-levels/\#44dc0663463.

Van, V. (2011). Core competence model. Retrieved October 9, 2016, from $\mathrm{http}: / / \mathrm{www}$. toolshero.com/leadership/core-competence-hamel-prahalad/.

Wan, K. (2013). The role of leadership in organizational transformation. Retrieved October 10, 2016, from https://www.cscollege.gov.sg/Knowledge/Pages/The-Role-of-Leadership-in-Organisational-Transformation. aspx.

\section{Web References}

http://www.baldrige21.com/BALDRIGE_GLOSSARY/BN/Core_Competencies.html

https://www.linkedin.com/pulse/20141013191210-28287374-strategy-management-tools

\section{Copyrights}

Copyright for this article is retained by the author(s), with first publication rights granted to the journal.

This is an open-access article distributed under the terms and conditions of the Creative Commons Attribution license (http://creativecommons.org/licenses/by/4.0/). 